\title{
Identifying Factors That Influence Pressure Ulcers by Numerical Simulation and Experimentation Methods
}

\author{
A Case Study \\ https://doi.org/10.3991/ijoe.v16i11.13817 \\ He-Thong Bui, Le-Van Nguyen, Anh-Ngoc Tran Ho \\ The University of Danang, Danang, Vietnam \\ Quang-Bang Tao ${ }^{(\varpi)}$, Thanh-Nghi Ngo \\ The University of Danang - University of Science and Technology, \\ Danang, Vietnam \\ tqbangedut. udn. vn
}

\begin{abstract}
In this study, the effects of pressure and temperature on pressure ulcers is investigated by using both numerical simulation and experimentation methods. Indeed, a biomechanical buttock-thigh tissue model is constructed along with wheelchair seat cushion. A human buttock-thigh model is created to perform thermo-mechanical simulations using the finite element method (Abaqus software). In parallel, experiments are conducted to determine the value of the pressure and the temperature distribution of the subject sitting on the wheelchair cushion (pressure pad and infrared camera). The preventive measures and appropriate treatments for people using a wheelchair or those with disabilities are measured. The findings show that the use of a wheelchair cushion reasonable for better distribution of pressure, decrease shear stress and improve the heat transfer between the contact surfaces of human buttock-thigh tissue and wheelchair cushion (reduce the temperature in the contact area). It contributes to the prediction of factors that can cause pressure ulcers to improve comfort seating and the quality of life for people with disabilities.
\end{abstract}

Keywords - Pressure ulcers, wheelchairs, numerical simulation, experimental, cushions.

\section{Introduction}

The damage localized skin or underlying tissues, usually happen over a bony prominence as a result of pressure or pressure in combination with shear and/or friction was called pressure ulcers (PU), also known as pressure sores, decubitus ulcers, and bedsores, and now referred to as pressure injuries [1]. The PU usually appears in people who have to sit in the same position for a long time and people who are bedridden, wheelchairs-confined, or unable to change their positions. PU becomes socio-economic problems, due to a significant increase in the number of people with disabilities, 
wheelchair users and treatment costs. Indeed, there are over 1 billion people with disabilities in over the world, of whom 2-4\% experience significant difficulties in functioning, according to a report of the World Health Organization (WHO) [2]. It is estimated that around 10 percent (100 million) people with disabilities need a wheelchair for their daily routines. For wheelchair users, PU a lot happens in areas of the ischial tuberosity, sacrum and the greater trochanter of the femur [3]. The cost of treatment up to £10,551 for a PU case depending on the level of PU (grade 1 to grade 4) [4] - [6], [15]. Every year in the UK, it is estimated that there are 412,000 individuals who will develop new PU [5]. Therefore, many studies have been conducted recently to identify the causes of $\mathrm{PU}$ and propose preventive measures.

PU have been interested and considered in recent years by many studies. Many internal and external factors contributing to the formation of PU were considered in few studies [8], [12], [13], [15]. We can indicate several causes of PU, such as: pressure, shear stress, friction, immobility, mobility problem, poor nutrition, ageing skin, health conditions. In particular, the pressure is considered as a major factor that causes PU for wheelchair users, disabled people sitting in the same position for a long time without changing positions [8], [13]. The skin and underlying soft tissues are deforms while pressure is applied to the skin, particularly over the ischial tuborosities (ITs). The muscle tissue compression will cause decreased blood flow and inadequate oxygenation (ischemia). The ischemia for a long time can cause aggregation of blood cells and cause a blockage of the capillaries, leading to cell death in the skin [13], [15], [16]. The capillary walls may also be damaged, allowing the red blood cells and liquid to pass into the interstitial space. This process results in non-disappearing erythema, skin discoloration, and induration in first stage. Prolonged ischemia will cause skin and tissue necrosis. This necrosis will increase and deepen in the tissue layers and this is the result of higher PU.

Shear and friction are often said in addition to pressure in the context of PU. The most recent definition of PU studied and reported periodically by the National Pressure Ulcer Advisory Panel (NPUAP) and the European Pressure Ulcer Advisory Panel (EPUAP) [13], [15]. These studies in Ref. [13], [15] have emphasized the role of pressure and designate that shear stress may be involved in association to concerning the formation and development of PU. In the context of deep tissue lesions, defined as "caused by underlying soft tissue damage related to pressure and/or shear". Although there is no consensus that friction is a direct cause of PU. Pressure and shear stress are also closely related: pressure on the soft tissues, especially above a bone projection, will cause some degree of shear by tissue deformation [13], [15].

We have mentioned the factors of pressure, shear and friction, which can cause pressure ulcers. In recent years, many studies have concentrated on the change of microclimate conditions to the formation and development of PU. The term "microclimate" in relation to PU generally refers today to: the temperature of the surface of the skin or tissues, and moisture or skin moisture at the interface between the human buttock-thigh and the support surface [13], [15], [17], [29]. The increase in body temperature is a recognized risk factor for PU. Therefore, significant attention to the microclimate factors to prevent PU is needed to reduce the current treatment cost for pathological PU. 
Some studies have undertaken clinical medical experiments to investigate the factors which can cause the PU [7]-[10]. However, these experimental studies are costly. Other studies have implemented a number of modeling and numerical simulations to provide predictions of PU that suggest prevention of PU [11], [12], [15], [19]-[21]. These studies have shown many causes of PU such as: pressure, shear forces, friction, moisture, stress inside the buttocks-thighs, temperature and humidity.

In this study, we will concentrate on the factors that can cause PU for wheelchair users, including pressure distribution, shear stress, stress on the buttock-thigh, and temperature by numerical simulations (using Finite Element Method-FEM) and experiment methods. The results obtained in this study demonstrate more clearly the development of PU for wheelchair users and provide preventive measures to reduce the level and progression of PU.

\section{Methodology}

In our study, we used two methods to identify these factors which can cause pressure ulcers. Firstly, the numerical simulation will be performed to identify the pressure distribution, stress inside buttock-thigh tissue human and temperature at the surface of buttocks-human/wheelchair cushion by finite element method (FEM). In the next step, we used an infrared camera and the pressure pad to study to measure the temperature and pressure distribution.

\subsection{Numerical simulation of thermal-mechanical}

A biomechanical buttock-thigh tissue model was established along with wheelchair seat cushions to study the influence of pressure and temperature to prevent PU for wheelchair users. The buttock-thigh tissue model was selected based on the ISO standards 16840-2:2007 [18] and developed from the human-buttock model as stated in Ref. [4], [11], [12], [15]. The model was designed by SOLIDWORKS ${ }^{\circledR}$ software as shown in Figure 1.

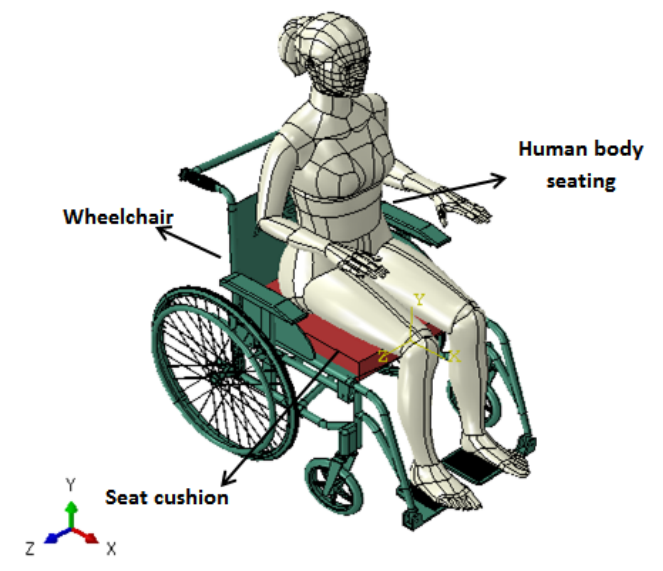


Fig. 1. Human body model using wheelchairs and seat cushions

In this numerical simulation, a human body model with $75 \mathrm{~kg}$ seating on the seat cushion of wheelchair was used as shown in Figure 1. We have applied a gravity field of $9.81 \mathrm{~m} / \mathrm{s}^{2}$ to the whole simulation environment and we assume that the wheelchair users would sit on seat cushion with real weight. The material property of the human body is complexity. To simplify this problem, we assumed that the buttock-thigh tissue model used in our study what the material properties are homogeneous, linear, isotropic, and incompressible. The material of finite element model used in this study is elasticity theory equation with large deformation. The Mooney-Rivlin hyperelastic model [4], [11], [12] was engaged for muscles comportment. The model was constructed on the strain energy function as indicated in Equation (1).

$$
U=C_{10}\left(\bar{I}_{1}-3\right)+C_{01}\left(\bar{I}_{2}-3\right)+\frac{2}{D_{1}}(J-1)^{2}
$$

where:

- $\mathrm{U}$ is the strain energy per unit of reference volume

- $\mathrm{C}_{10}, \mathrm{C}_{01}$ and $\mathrm{D}_{1}$ are temperature-dependent material parameters

- $\overline{\mathrm{I}}_{1}, \overline{\mathrm{I}}_{2}$ are two invariants of the iso-volumic form tensors of Cauchy-Green strain

- $\mathrm{J}$ is the total volume ratio

- The parameters $\mathrm{C}_{10}, \mathrm{C}_{01}$ and $\mathrm{D}_{1}$ were taken as well as Table 1, respectively [4], [11], [12], [15], [19], [20].

Table 1. The Mooney-Rivlin hyperelastic parameters of buttock-thigh tissue

\begin{tabular}{|c|c|c|}
\hline $\boldsymbol{C}_{\mathbf{1 0}}, \mathbf{k P a}$ & $\boldsymbol{C}_{\mathbf{0 1}}, \mathbf{k P a}$ & $\boldsymbol{D}_{\mathbf{1}}, \mathbf{k P a}^{-\mathbf{1}}$ \\
\hline 1.65 & 3.35 & 2 \\
\hline
\end{tabular}

The time base Prony-series model with the viscoelastic behavior of the buttock-thigh tissue base Ref. [4], [15], [19], [20] was used in our study. Time-dependent shear relaxation modulus $\mathrm{G}(\mathrm{t})$ is given by equation (2):

$$
G(t)=G_{0}-\sum_{i=1}^{N} G_{i}\left(1-e^{\frac{-t}{\tau_{i}^{G}}}\right)
$$

where: $\mathrm{G}_{\mathrm{i}}$ (the relaxation magnitude) and $\tau_{i}^{G}$ (the relaxation time) are material dependent parameters and $\mathrm{N}$ is the order of the Prony-series $(\mathrm{N}=1$ in the present work). The viscoelastic parameters for the buttock-thigh tissue was set as indicated in Table 2 [4], [15], [19], [20].

Table 2. The viscoelastic material parameters of buttock-thigh tissue

\begin{tabular}{|c|c|c|}
\hline $\mathbf{g}_{\mathbf{1}}(-)$ & $\mathbf{k}_{\mathbf{1}}(-)$ & $\tau_{\mathbf{1}}(\mathbf{s})$ \\
\hline 0.5 & 0.5 & 0.8 \\
\hline
\end{tabular}

The charging and boundary conditions between the human body and wheelchair seat cushion is showed as in Figure 2a. In this simulation, the bottom surface of wheelchair 
seat cushion is fixed. This study was permitted to quantify the impact of the load of human body used in on the cushion in the $\mathrm{Y}$ axis. The mesh of model FEM is showed as in Figure 2b. The mesh is composed of 357051 linear elements (including 94080 hexahedrons C3D8R, 262971 tetrahedrons C3D4) and 103275 nodes. The contact pair algorithm (a penalty contact with surface to surface) with a coefficient of friction 0.5 was used in the interaction between the buttock-thigh tissue and wheelchair seat cushion models, and this simulation was investigated in ABAQUS ${ }^{\circledR} /$ Explicit 6.13 , as stated in [12], [19], [20].

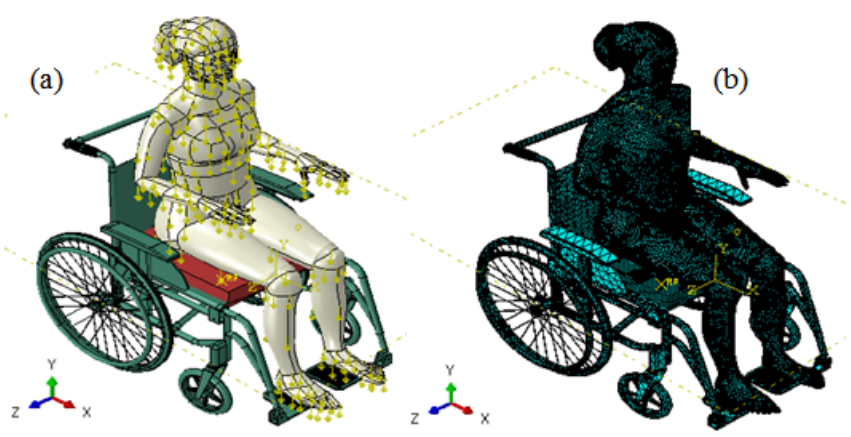

Fig. 2. Human body model using wheelchairs and cushions

The flat cushion on the market, with dimensions $\mathrm{L} \times \mathrm{W} \times \mathrm{H}$ (Length $\mathrm{x}$ Width $\mathrm{x}$ Height) $=460 \times 410 \times 70 \mathrm{~mm}$, is a "Polyurethane" (PUR) foam material was used in this work. The mechanical properties are: hyperelastic and viscoelastic (non-linear, isotropic, and compressible) were used for this wheelchair seat cushion. The constitutive relation of seat cushion foam was selected to model is the hyper-elastic material. The strain energy function of hyper-elastic material is defined as following equation (3) [4], [19]-[20]:

$$
U=\sum_{i}^{N} \frac{2 \mu_{i}}{\alpha_{i}^{2}}\left\{\lambda_{1}^{\alpha^{\alpha_{i}}}+\lambda_{2}^{\alpha_{i}}+\lambda_{3}{ }^{\alpha_{i}}-3+\frac{1}{\beta_{i}}\left[\left(J^{e l}\right)^{-\alpha_{i} \beta_{i}}-1\right]\right\}
$$

where: $\mathrm{U}$ - the strain energy potential, $\mathrm{N}$ - is the order of the strain energy potential, $\mu_{\mathrm{i}}, \alpha_{\mathrm{i}}, \beta_{\mathrm{i}}$ - are the temperature-dependent material parameters, $\lambda_{\mathrm{i}}$ - Principal stretch ratios, $\mathrm{J}_{\mathrm{el}}$ - is the ratio of elastic-deformation to volume-change. In the present work, the second order strain energy function was used $(\mathrm{N}=2)$. The "hyperfoam" parameters of seat cushion material (PUR) are determined in our simulation by software ABAQUS ${ }^{\circ}$, with the parameters were summarized as the following: $\mu_{1}=164.861 \mathrm{kPa}$; $\alpha_{1}=8.88413 ; \beta_{1}=0$ and $\mu_{2}=0.023017 \mathrm{kPa} ; \alpha_{2}=-4.818 ; \beta_{2}=0$.

The viscoelastic comportment of the seat cushion is defined by using a time-base Prony-series model as stated in Ref. [4], [19], [20]. The time-dependent shear relaxation modulus $\mathrm{G}(\mathrm{t})$ is given in equation (2). The viscoelastic parameters for the wheelchair seat cushion (PUR) model were as follows: $G_{1}=0.3003 ; \tau_{1}=0.010014 \mathrm{~s}$ and $G_{2}=0.1997 ; \tau_{2}=0.002 \mathrm{~s}[4],[19]$, [20]. 
Thermal comfort is the person who perceives satisfaction with the surrounding ambient conditions. The thermal location is evaluated by a subjective evaluation based on the study of these references [22]. The heat transfer mechanism that happens in living tissue in the so-called bio-heat formulated has developed by Pennes [23] and Fiala [24]. The differential equation describes the heat dissipation in homogeneous, infinite tissue volume:

$$
k\left(\frac{\partial^{2} T}{\partial r^{2}}+\frac{\omega}{r} \frac{\partial T}{\partial r}\right)+q_{m}+\beta\left(T_{b}-T\right)=\rho C v \frac{\partial T}{\partial t}
$$

where, $\mathrm{k}$ is the tissue thermal conductivity $\left[\mathrm{W} \cdot \mathrm{m}^{-1} .{ }^{\circ} \mathrm{C}^{-1}\right]$; $\mathrm{T}$ is the tissue temperature $\left[{ }^{\circ} \mathrm{C}\right] ; \mathrm{q}_{\mathrm{m}}$ is the metabolic heat flow density $\left[\mathrm{W} . \mathrm{m}^{-3}\right]$; for all body elements $\mathrm{r}$ denotes the radial coordinate $[\mathrm{m}] ; \omega$ is a geometry factor; $\beta\left(\mathrm{T}_{\mathrm{b}}-\mathrm{T}\right)$ is blood perfusion, with $\beta=$ $\rho_{\mathrm{bl}} \cdot \mathrm{w}_{\mathrm{bl}} \cdot \mathrm{c}_{\mathrm{bl}}$ ( $\beta$ is heat convection term, where $\rho_{\mathrm{bl}}$ is density of blood $\left[\mathrm{kg} \cdot \mathrm{m}^{-3}\right], \mathrm{w}_{\mathrm{bl}}$ is blood perfusion rate $\left[\mathrm{m}^{3} \cdot \mathrm{s}^{-1} \cdot \mathrm{m}^{-3}\right], \mathrm{c}_{\mathrm{bl}}$ is heat capacitance of blood $\left.\left[\mathrm{J} \cdot \mathrm{kg}^{-1} \cdot{ }^{\circ} \mathrm{C}^{-1}\right]\right) ; \mathrm{T}_{\mathrm{b}}$ is the arterial blood temperature $\left[{ }^{\circ} \mathrm{C}\right]$. This combined effect is balanced by the storage of heat within the tissue mass (right-hand side of equation, where $\rho$ is tissue density $\left[\mathrm{kg} . \mathrm{m}^{-}\right.$ $\left.{ }^{3}\right], C_{v}$ is tissue heat capacitance $\left[\mathrm{J} . \mathrm{kg}^{-1} .{ }^{\circ} \mathrm{C}^{-1}\right], \mathrm{t}$ is time $\left.[\mathrm{s}]\right)$. We fixed $34^{\circ} \mathrm{C}$ according to Ref. [23] for the modelization of human buttock-thigh tissue. The synopsis of the heat transfer modeling is presented in Figure 3.

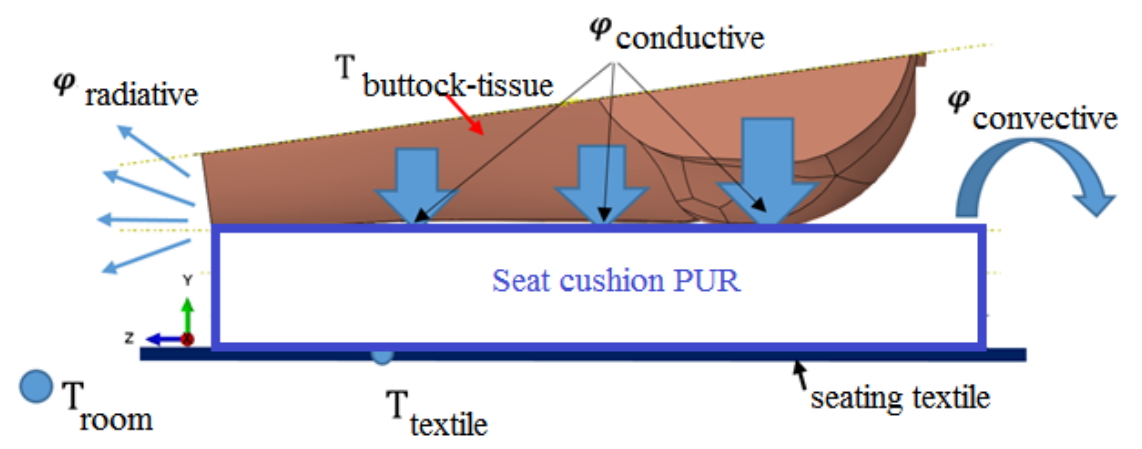

Fig. 3. Synopsis of the heat transfer modeling

The temperature distribution in the polyurethane foam cushion in contact with the human buttock-thigh tissue was simulated as a function of time by a finite element method. The general governing equation can be presented as [25]:

$$
\rho C v \frac{\partial T}{\partial t}=k \nabla^{2} T+S
$$

where: $\mathrm{T}\left[{ }^{\circ} \mathrm{C}\right]$ is the polyurethane foam cushion local temperature, $\mathrm{t}[\mathrm{s}]$ is varies with spatial coordinates and time. The thermal physical properties $\mathrm{k}, \rho$, and $\mathrm{C}_{\mathrm{v}}$ are the material thermal conductivity $\left[\mathrm{W} \cdot \mathrm{m}^{-1} \cdot{ }^{\circ} \mathrm{C}^{-1}\right]$, density $\left[\mathrm{kg} \cdot \mathrm{m}^{-3}\right]$ and specific heat $\left[\mathrm{J} \cdot \mathrm{kg}^{-1} \cdot{ }^{\circ} \mathrm{C}^{-1}\right]$, respectively. The source term, $\mathrm{S}$ is heat generation per unit volume for the nodes. In our simulation, the polyurethane foam cushion without cover and the temperature is considered to be at $20^{\circ} \mathrm{C}$, which is the ambient temperature ( $\left.\mathrm{T}_{\text {room }}\right)$ was applied. The heat 
exchange equation between two contacts is showed as equation (5), which means the contact areas between the human buttock-tissue and the polyurethane foam cushion. For non-contact areas, the heat exchange between the human buttock-tissue, the wheelchair seat cushion and the ambient air happen by convection and radiation. The effective local heat transfer coefficient can be defined as equation (6):

$$
\varphi=\varphi_{r}+\varphi_{c}=\sigma \in\left(\bar{T}^{4}-T_{\infty}{ }^{4}\right)+\bar{h}_{c}\left(\bar{T}-T_{\infty}\right)
$$

The thermal simulation for the right half of the human buttocks-tissues and the polyurethane foam cushion was performed by software ABAQUS ${ }^{\circledR} /$ Standard 6.13-4. The thermal parameters of the buttock-thigh tissue and polyurethane foam materials were showed in Table 3 [26]-[28].

Table 3. Thermal properties of human buttocks-tissues and polyurethane foam cushion at room temperature for our simulation

\begin{tabular}{|c|c|c|c|}
\hline Materials & $\begin{array}{c}\text { Thermal conductivity } \\
\left(\mathrm{W} \cdot{ }^{0} \mathbf{C}^{-1} \cdot \mathrm{m}^{-1}\right)\end{array}$ & 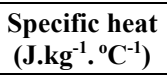 & $\begin{array}{l}\text { Density } \\
\left(\mathrm{kg} \cdot \mathrm{m}^{-3}\right)\end{array}$ \\
\hline Buttock-tissue & 0.4 & 3470 & 1100 \\
\hline PUR foam cushion & 0.033 & 1100 & 175 \\
\hline
\end{tabular}

\subsection{Experimentation}

A pressure pad and an infrared camera (Fig. 4 and Fig. 5) were used to determine the pressure distribution and temperature at the contact surface (between the buttock-thigh tissue and wheelchair seat cushion). A healthy man participated in the experimentation. The principal characteristics of subject are summarized in Table 4. The subject was informed by the nature, purpose and duration of the study.

Table 4. Anthropometric characteristics of the subject

\begin{tabular}{|l|c|}
\hline \multicolumn{2}{|c|}{ Subject } \\
\hline Weight $(\mathrm{kg})$ & 75 \\
\hline Age (year) & 34 \\
\hline Size (cm) & 173 \\
\hline IMG (\%) & 21.69 \\
\hline
\end{tabular}

The subject was installed in a wheelchair respectively a pressure pad as shown in Fig. 4 with seat cushion polyurethane foam (PUR) like in the numerical simulation by the ABAQUS ${ }^{\circ}$ software and an infrared camera as shown in Figure 5.

The pressure pad is called "TEXIMAT" pressure pad and developed by TEXISENSE Company as shown in Fig. $4 \mathrm{~b}$, which is $50 \mathrm{~cm}$ x $50 \mathrm{~cm}$ in dimensions and comprises of 32 pixels $x 32$ pixels. The data is collected, stored, analyzed and displayed on a personal computer by the TEXIMONITOR software [14]. The sensor comprised $32 \times 32$ pixels and permits recording the pressure distribution on the human buttocktissue and wheelchair seat cushions at 1024 points. 


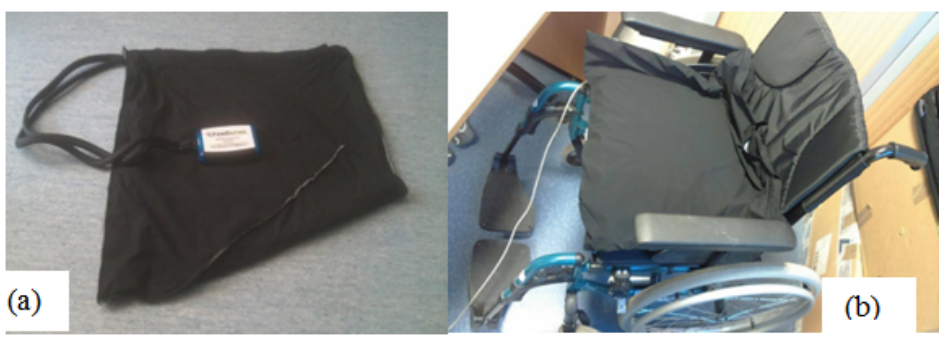

Fig. 4. Pressure pad (a) and installation this pad in the wheelchair (b)

The infrared camera is a CEDIP TITANIUM with high performance and having $640 \times 512 \mathrm{InSb}$ detectors (quantum efficiency (> $70 \%$ )) matrix. The spectral response is $1.5 \mu \mathrm{m}$ to $5 \mu \mathrm{m}$. It has a variable integration time from $3 \mu \mathrm{s}$ to $1 \mathrm{~ms}$ and allowing a typical measuring range from $-20^{\circ} \mathrm{C}$ to $3000^{\circ} \mathrm{C}$ at a rate of up to 100 frames/second in the full frame mode. Indeed, in the camera software interface, for this experiment the temperature range from $20^{\circ} \mathrm{C}$ to $35^{\circ} \mathrm{C}$ was selected in order to increase the sensitivity and so increasing the accuracy, too.

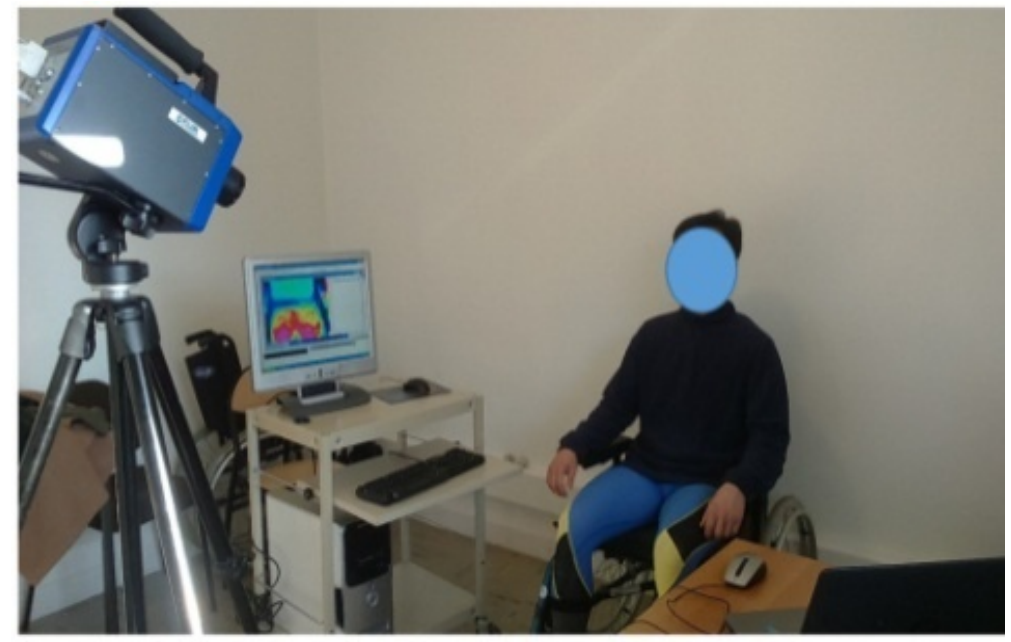

Fig. 5. Installation and set-up of the subject and the infrared camera on the wheelchair

The temperature measurements were taken with an infrared camera before the effort like reference " 0 ". Then the camera recorded the temperatures at the surface of the cushion respectively after $6 \mathrm{~min}$ sitting, $22 \mathrm{~min}$ and then at least after $35 \mathrm{~min}$ sitting on the wheelchair at six zones as shown in Figure 6. 


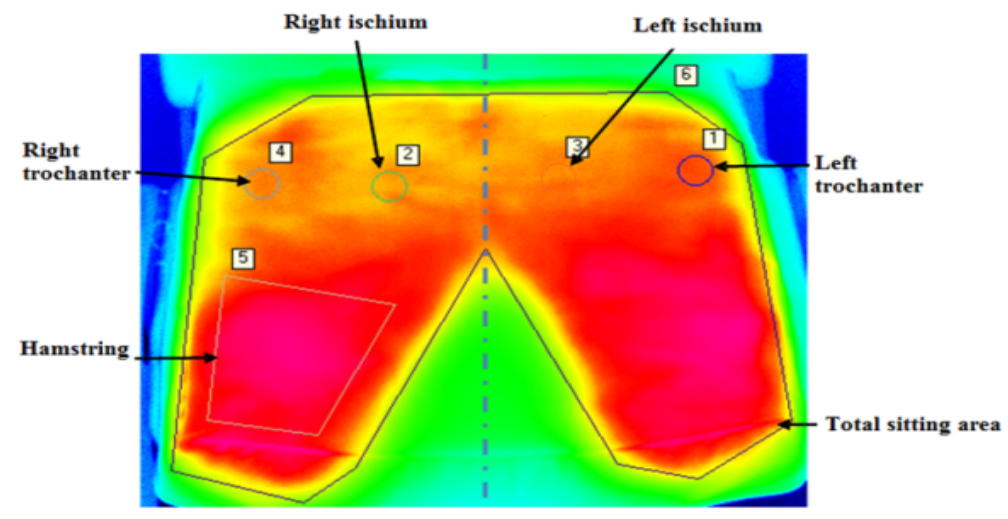

Fig. 6. Selecting measurement area after cushions subject sitting.

\section{$3 \quad$ Results and Discussions}

\subsection{Pressure distribution}

The peak contact pressure distribution of $36 \mathrm{kPa}$ was focused in the buttock-thigh tissue in the case buttock-thigh tissue interacts with polyurethane foam cushion as shown in Fig. 7a. The value pressure distribution is concentrated mainly in the center of the seat cushion and buttock-thigh tissue. This location is a common occurrence of PU for wheelchair users or people with disabilities. Therefore, the best of redistribution pressure will contribute significantly to improve the comfort of the sitting position and pressure ulcers prevention. This result compared with results obtained $(175.8 \mathrm{kPa}$ and $187.7 \mathrm{kPa}$ ) [12], [19] which subjects were modeled in the same sitting position, this study's results yield toward a reduction in contact pressure of about 5 times. This difference is explained by the total contact surface between the cushion and the buttockthigh tissue. In our numerical simulation, the contact surface is larger than the studies in Ref. [12], [19]. This result indicates that PUR cushions in our study should be of interest in biomedical engineering to redistribute pressure, reduce PU for the disabled and wheelchair users.
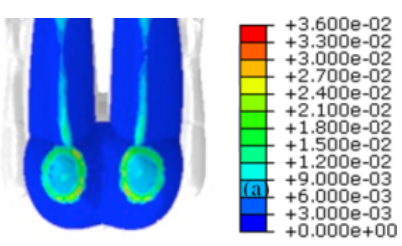

a) Numerical simulation

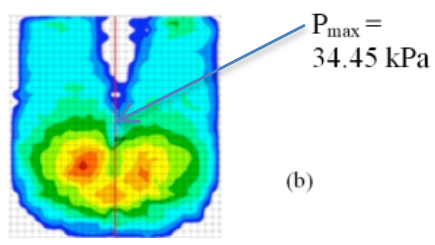

b) Experimentation

Fig. 7. Pressure distribution on the interface of buttock-thigh tissue 
Figure $7 \mathrm{~b}$ shown the results achieved from experimentations based on TexiMonitor software connected to a computer for seat wheelchair cushion (PUR cushion). The pressure distribution of wheelchair cushion is shown for example. We can observe the variability of the pressure distribution according to the property and characteristics of cushion. The pressure distribution results obtained for this cushion showed that the peak value of pressure is concentrated respectively in ITs (the high-pressure value obtained). The peak pressure distribution on the PUR seat cushion of our study obtained 34.45 $\mathrm{kPa}$. This result is correspondent with the results on the numerical simulation $(36 \mathrm{kPa})$, with an error of about $4,3 \%$. The error can be explained that for numerical simulation results, a buttock-thigh tissue model without a thin layer of underwear was used. While the experimental setup, the subject wearing thin underwear.

The pressure distribution was not the same in the left and right buttock-thigh tissues which was explained that the subject closed their eyes and sat naturally in the experimental positions. So, the subject will not be able to adjust the balance of the pressure distribution for the left and right. However, the peak distribution pressure values measured by the two methods are equivalent.

\subsection{Shear stresses distribution}

The shear stress was obtained under the constant coefficient of friction in static condition (0.5), is shown in Figure 8. In this study's model, the peak shear stress value is $10.13 \mathrm{kPa}$, compared with $56.56 \mathrm{kPa}$ as stated in Ref. [12].
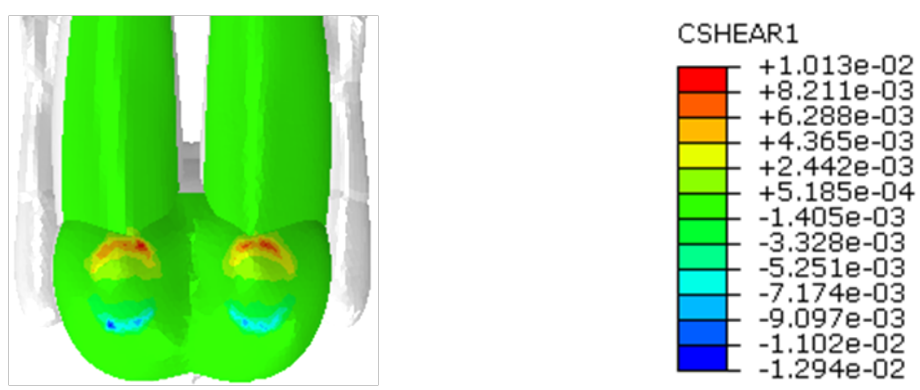

Fig. 8. Shear stresses at the interface buttock-thigh tissue

The differences in this value may be explained by the differences in the material and structure used for the two cushions, i.e. in the study [12] the honeycomb cushion with contacted edge versus the polyurethane foam with flat contact surface used in our study. Indeed, the contact area between the buttock-thigh tissue and the cushion PUR foam in our case is larger than their case. This explains why the shear stress distribution was reduced. 


\subsection{Temperature distribution}

The peak temperature obtained is $34.21^{\circ} \mathrm{C}$ for the time interval $35 \mathrm{~min}$ of numerical simulation, shows as Fig. 9. This figure shows that almost the largest temperature values are concentrated in the center of the PUR and the buttock thigh-tissue at large contact. At other locations on the seat PUR, these locations are far from the buttock-tissue (no direct contact with the buttock-tissue), which have lower temperature. The temperature of simulation was performed with the buttock-thigh tissue model excluding the skin layer and underwear. Indeed, the results obtained in this study are larger than the experimental results with real subjects and wearing underwear.

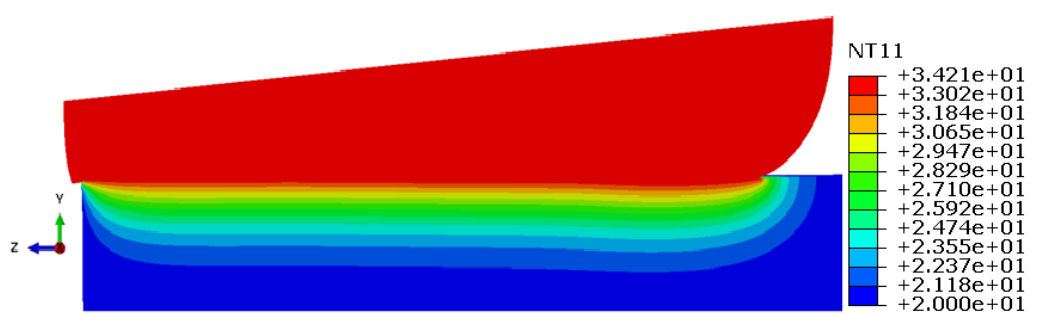

Fig. 9. Temperature distribution between the buttocks and the PUR foam cushion

Fig. 10 shown the results of the temperature after the cushion utilization with the same protocol cited above. The peak temperature obtained was $31.75^{\circ} \mathrm{C}$ after $35 \mathrm{~min}$. The difference in maximum temperature value between numerical simulation and experimental results is explained by the subject wear underwear and performed the standup and sit-down operation for the infrared camera to record surface temperature value of wheelchair cushion. Therefore, there is always a loss of heat due to the travel time of the object after each measurement.

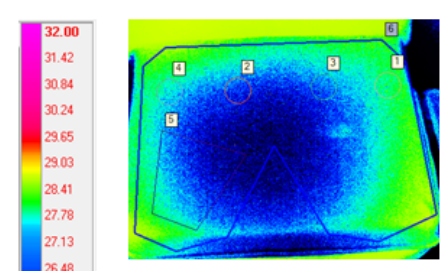

(a) before sitting

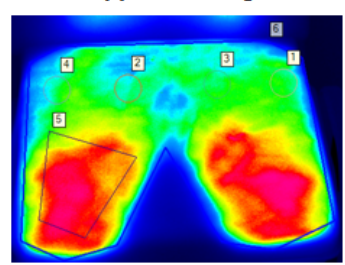

(c) 22 min after sitting

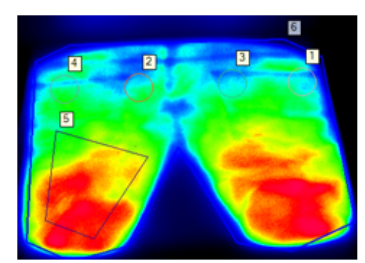

(b) 6 min after sitting

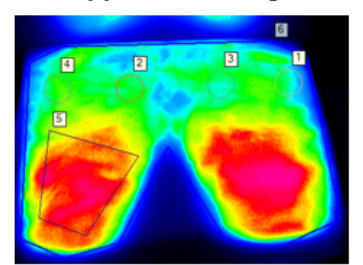

(d) 35 min after sitting

Fig. 10. Thermal mapping at the surface of the polyurethane foam cushion after 35 minutes sitting 
It can be seen that the highest temperature on the PUR seat cushion surface is concentrated in hamstring region (zone number 5), and the low temperature is concentrated in its region (zones numbers 2 and 3). This can be explained that under influence of body weight, pressure compress muscle tissue in the ischial tuborosities (ITs) area, which makes it difficult for blood circulation and it causes dead skin cells due to the lack of oxygen, the pressure effects in a long time will cause pressure ulcer disease in this area (zones numbers 2 and 3). Indeed, compared to other zones (zones numbers 1 , 4 and 5), in zones numbers 2 and 3 (ITs zones) have been shown by many studies to be the zones where pressure ulcers often occur in bedridden patients and in wheelchair users for long periods of time without changing positions.

Concerning the zones evolution, the temperature changed depending on measured areas. It started around $20^{\circ} \mathrm{C}$ at the surface of the cushion (initial temperature) and subsequently increased before stabilizing around $25 \mathrm{~min}$. The higher temperature observed at hamstring area was $31.21^{\circ} \mathrm{C}$ after $35 \mathrm{~min}$ and increased by $13.21^{\circ} \mathrm{C}$ in reference to the initial temperature of $20^{\circ} \mathrm{C}$. The ischium and trochanter zones reached respectively $29.59^{\circ} \mathrm{C}$ and $30.20^{\circ} \mathrm{C}$ (Table. 5).

Table 5. The temporal variation of the highest temperatures of the six measuring zones areas of PUR seat cushion

\begin{tabular}{|c|c|c|c|c|c|c|}
\hline$\lambda_{e^{\prime} m_{p_{0}}}$ Zones & $\begin{array}{c}\text { Trochan- } \\
\text { ter left }\end{array}$ & $\begin{array}{c}\text { Ischium } \\
\text { right }\end{array}$ & $\begin{array}{c}\text { Ischium } \\
\text { left }\end{array}$ & $\begin{array}{l}\text { Trochan- } \\
\text { ter right }\end{array}$ & Hamstring & $\begin{array}{c}\text { Total } \\
\text { sitting } \\
\text { area }\end{array}$ \\
\hline Temp. Min. & 28.44 & 28.23 & 28.79 & 29.28 & 29.15 & 22.27 \\
\hline Temp. Med. & 29.57 & 28.68 & 29.15 & 29.73 & 30.25 & 29.14 \\
\hline Temp. Max. & 30.22 & 29.08 & 29.59 & 30.20 & 31.21 & 31.75 \\
\hline Temp. difference & 1.78 & 0.85 & 0.80 & 0.93 & 2.06 & 9.48 \\
\hline
\end{tabular}

\section{Conclusion}

This study identifies factors that cause the PU such as pressure distribution, shear, temperature and friction by two basic methods: numerical simulation and experimentation. The numerical simulation results shown pressure distribution for PUR cushions in this study, the pressure distribution value reduced of approximately 5 times the honeycomb cushions. This result is also proved by experiment, utilizing pressure-pad with an error $4.3 \%$. It can be concluded that this is a very positive research result for us to help prevent PU by redistributing pressure values. In addition, the results obtained from thermal infrared experiments and finite element simulations of thermomechanical help us identify zones at risk of PU.

These results may help to develop prevention methods for PU disease for wheelchair users and people with disabilities. Preventive measures include the use of a wheelchair cushion reasonable for better distribution of pressure, decrease shear stress and improve 
the heat transfer between the contact surfaces of human buttock-thigh tissue and wheelchair cushion (reduce the temperature in the contact area).

In the future, the effect of different cushions, the buttock-thigh tissue with the skeletal system, with underwear on both experimental and numerical models to provide a better method for selecting wheelchairs seat cushions will be focused.

\section{$5 \quad$ Acknowledgement}

This research was supported by the University of Danang under grant number B2018-ĐN06-12.

\section{References}

[1] Pressure ulcers. Available: https://en.wikipedia.org/wiki/Pressure ulcer. [Accessed: Jun. 24, 2019].

[2] Disability and health, "World Health Organization: WHO'. Available: https://www. who.int/news-room/fact-sheets/detail/disability-and-health [Accessed: April. 22, 2020].

[3] Protecting wheelchair users from pressure ulcers. Available: https://www.healthproductsforyou.com/ar-protecting-wheelchair-users-from-pressure-ulcers.html. [Accessed: Jun. 24, 2019].

[4] Bui, H.T., Lestriez, P., Nguyen, T.N.P., Nguyen, L.V., Tao, Q.B., Debray, K., Nguyen, T.H.V., \& Taiar, R. (2018, Oct.). The Evaluation of the Interaction between Human Buttocks Thighs and Wheelchair Seat Cushion to Prevent PU Using Finite Element Analysis. Proceeding of 1st International Conference on Human Systems Engineering and Design (IHSED2018): Future Trends and Applications, Reims, France. https://link. springer.com/chapter/10.1007\%2F978-3-030-02053-8 137. https://doi.org/10.1007/978-3030-02053-8 137

[5] Bennett, G., Dealey. C., \& Posnett, J. (2004). The cost of pressure ulcer in the UK. Age and Ageing. 33 (3), 230-235. https://doi.org/10.1093/ageing/afh086

[6] Bhattacharya, S. \& Mishra, R. K. (2015). Pressure ulcers: Current understanding and newer modalities of treatment. Indian J Plast Surg. 48(1), 4-16. https://doi.org/10.4103/0970$\underline{0358.155260}$

[7] Vasiliki Bravou, \& Athanasios Drigas. (2019). A Contemporary View on Online and Web Tools for Students with Sensory \& Learning Disabilities. iJOE. 15(12), 97-105. https://doi. org/10.3991/ijoe.v15i12.10833.

[8] Kruger, E.A., Pires, M., Ngann, Y., Sterling, M., \& Rubayi, S. (2013). Comprehensive management of PU in spinal cord injury: Current concepts and future trends. The Journal of Spinal Cord Medicine. 36(6), 572-585. https://doi.org/10.1179/2045772313y.00000000 $\underline{93}$

[9] Sharon, E.S., Teddie, E.V., Thomas, W.J., \& Stephen, H.S. (2014). Effects of Wheelchair Cushions and Pressure Relief Maneuvers on Ischial Interface Pressure and Blood Flow in People with Spinal Cord Injury. Archives of Physical Medicine and Rehabilitation. 95(7), 1350-1357. https://doi.org/10.1016/j.apmr.2014.01.007.

[10] Mendes, P.V.B., Gradim, L.C.C., Silva, N.S., Allegretti, A.L.C., Carrijo, D.C.M., \& Cruz, D.M.C.D. (2018). Pressure distribution analysis in three wheelchairs cushions of subjects 
with spinal cord injury. Disability and Rehabilitation: Assistive Technology. 14(6), 555-560. https://doi.org/10.1080/17483107.2018.1463399.

[11] Bui, H.T, Pradon, D., Lestriez, P., Debray, K., \& Taiar. R. (2017). The prevention of PU: biomechanical modelization and simulation of human seat cushion contributions. Proceeding of International Conference on Advances in Computational Mechanics (ACOME), Phu Quoc Island, Vietnam. https://doi.org/10.1007/978-981-10-7149-2 80.

[12] Bui, H.T., Lestriez, P., Pradon, D., Debray, K., Abdi, E., \& Taiar, R. (2018). Biomecha nical modeling of medical seat cushion and human buttock-tissue to prevent PU. Russ. J. Biomec. 22(1), 37-47. https://doi.org/10.15593/RJBiomechh/2018.1.04

[13] International Review : Pressure ulcer prevention: pressure, shear, friction and microclimate in context. (2010). A consensus document. London : Wounds International. Available: https://www.woundsinternational.com/resources/details/international-review-pressure-ulcer-prevention-pressure-shear-friction-and-microclimate-context. [Accessed: Jan. 11, 2020]. https://doi.org/10.1016/j.clinbiomech.2018.09.010

[14] Texisense. (2019). La nappe de pression. Available: http://www.texisense.com/. [Access ed: Jun. 24, 2019].

[15] Bui, H.T., (2018). Modélisation et optimisation de l'assise d'un fauteuil roulant pour handicapés afin d'améliorer le confort du point de vue médical. Thèse à l'Université de Reims Champagne-Ardenne. Available: http://www.theses.fr/2018REIMS005. [Accessed : Jun. 24, 2019].

[16] Humberto A. Silva. (2019). Multi-Model Adaptive Predictive Control System for Automated Regulation of Mean Blood Pressure. iJOE. 15(11), 69-87. https://doi.org/10. 3991/ijoe.v15i11.10912

[17] Pron, H., Taiar, R., Bui, H.T., Lestriez, P., \& Polidori, G., (2017). Infrared thermography applied to the study of the thermal behavior of wheelchair cushion. Computer Methods in Biomechanics and Biomedical Engineering. 20 (s.1), 167-168. https://doi.org/10.1080/102 $\underline{55842.2017 .1382915}$

[18] ISO 16840-2:2007. Wheelchair seating - Part 2: Determination of physical and mechanical characteristics of devices intended to manage tissue integrity -- Seat cushions. Available: https://www.iso.org/standard/40980.html. [Accessed: Jun. 24, 2019]. https://doi.org/10. $\underline{3403 / 30117792}$

[19] Grujicic, M., Pandurangan, B., Arakere, G., Bell, W.C., He, T., \& Xie, X. (2009). Seatcushion and soft-tissue material modeling and a finite element investigation of the seating comfort for passenger-vehicle occupants. Materials \& Design. 30 (10), 4273-4285. https://doi.org/10.1016/j.matdes.2009.04.028

[20] Tang, C.Y., Chan, W., \& Tsui, C.P. (2010). Finite element analysis of contact pressures between seat cushion and human buttock-thigh tissue. Engineering. 2 (9), 720-726. https://doi.org/10.4236/eng.2010.29093

[21] Munandar, I., Huzni, S., Ismail, M.S., Shaari, M.S., \& Ariffin, A.K. (2017). Pressure sores of human tissue damage during pelvic binder compression. International Journal of Automotive and Mechanical Engineering. 13(3), 3696 - 3709. https://doi.org/10.15282/ ijame.13.3.2016.13.0303

[22] Zaina Norhallis Zainol, Masine Md. Tap, Haslinda Mohamed Kamar, \& Nazri Kamsah. (2019). Heat Transfer Model to Predict Human Skin Temperature under Comfort Level by using Bioheat Equation. iJOE. 15(12), 52-64. https://doi.org/10.3991/ijoe.v15i10.10876

[23] Pennes, H. H. (1948). Analysis of tissue and arterial blood temperatures in the resting human forearm. J. Appl. Physiol. 1(2), 93-121. https://doi.org/10.1152/jappl.1948.1.2.93 
[24] Fiala, D. (1998). Dynamic simulation of human heat transfer and thermal comfort. Thesis institute of energy and sustainable development De Montfort University Leicester. Available: http://hdl.handle.net/2086/4129. [Accessed: Jan. 6, 2020].

[25] Karimi, G., Chan, E.C., \& Culham, J.R. (2004). Thermal Modeling of Driver/Seat Interfaces in Automotive Applications. SAE International in United States. https://doi.org/ 10.4271/2004-01-2143

[26] Paulke, D.S. (2013). The Application of Thermal Simulation Techniques for Seat Comfort Optimizations. Available: https://www.semanticscholar.org/paper/The-Application-ofThermal-Simulation-Techniques-Paulke/9eec060b9eba08cbd373be2a816fb3a30a2de86a. [Accessed: Jan. 6, 2020].

[27] Calvert, J., Duck, F., Clift, S., \& Azaime, H. (2007). Surface heating by transvaginal transducers. Ultrasound Obstet Gynecol. 29 (4), 427-432. https://doi.org/10.1002/uog.3973

[28] Shaw, A., Pay, N. M., Preston, R.C., \& Bond, A.D. (1999). Proposed standard thermal test object for medical ultrasound. Ultrasound Med Biol. 25 (1), 121-132. https://doi.org/10. 1016/s0301-5629(98)00136-7

[29] Olney, C. M., Simone, A., Hanowski, K., Rector, T. S., Goldish, G. D., Hansen, A. H., \& Ferguson, J. E. (2018). Microclimate evaluation of strap-based wheelchair seating systems for persons with spinal cord injury: A pilot study. Journal of tissue viability, 27(3), 181-187. https://doi.org/10.1016/j.jtv.2018.06.001

\section{Authors}

He-Thong Bui is a senior lecturer in Mechanical Engineering Department, University of Technology and Education - The University of Danang, Vietnam. He obtained his PhD. in Biomechanical Engineering at University of Reims Champagne-Ardenne, France in 2018. His present research interests include: Biomechanics and Biomedical Engineering, Disability, Pressure Ulcers, Finite Element Modeling. (Email: bhthong@ute.edu.vn)

Le-Van Nguyen is a lecturer in Industrial Education Department, University of Technology and Education - The University of Danang, Vietnam. He received the MSc. Degree in 2015 at the Chinese Culture University (CCU), Taiwan. His field of research interests is biomedical engineering and mechanical engineering. (Email: nlvan@ute.edu.vn)

Anh-Ngoc Tran Ho is a senior lecturer in Mechanical Engineering Department, University of Technology and Education - The University of Danang, Vietnam. He obtained his PhD. in Mechanical Engineering at University of Da Nang, Viet Nam in 2014. (Email: htangoc@ute.edu.vn)

Quang-Bang Tao is a senior lecturer in Faculty of Mechanical Engineering, University of Science and Technology - The University of Danang, Vietnam. He obtained his PhD. in Mechanical and Automation Engineering at University of Paris Saclay, France in 2016. His present research interests include: Finite Element Analysis, Mechanical Properties, Mechanics of Materials and Fracture Mechanics. (Email: tqbang@,dut.udn.vn 
Thanh-Nghi Ngo is a lecturer in Faculty of Mechanical Engineering, University of Science and Technology - The University of Danang, Vietnam. He obtained his PhD. in Industrial Engineering at Centrale Nantes, France in 2018. His field of research interests is biomedical engineering and PLM. (Email: ntnghi@dut.udn.vn)

Article submitted 2020-02-20. Resubmitted 2020-07-02. Final acceptance 2020-07-02. Final version published as submitted by the authors. 